<原 著 $>$

\title{
コルチコステロイド剤の $\mathrm{HBe}$ 抗原抗体系の seroconversion に及ぼす影響について
}

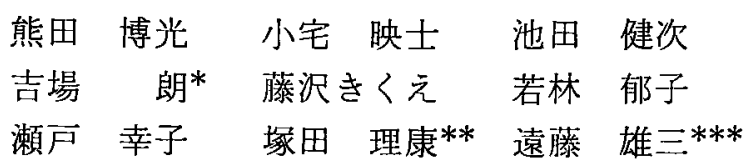

要 旨 : 過去 8 年間に腹腔鏡・肝生愉を施行した e 抗原陽性慢性肝炎 31 例について e 抗原から $\mathrm{e}$ 抗体への seroconversion とステロイド剤との関係について検討した. 31例中 6 例にコルチコステ ロイド剤を使用したところ，6例全例にコルチコステロイド剤中止後, 或いは減量中に血清トラ ンスアミナーゼの rebound 現象が起こることにより e 抗原から e 抗体に seroconversion した。 一 方，コルチコステロイド剤を使用しなかった25例では10例（40\%）にe 抗体への seroconversion が認められたにすぎなかった、コルチコステロイド剤を使用した 6 例は，血清トランスアミナー ゼが高值の時期にステロイド剤を初回 $40 \mathrm{mg}$ (一部 $30 \mathrm{mg}$ ) 連日使用し，1週間ごとに漸減し，漸 減後は10mg 隔日にて 2 カ月から 33 力月の長期に渡って使用し, 血中 HBs 抗原の titer が， $2^{7}$ から $2^{10}$ をで低下した時点でかつ血清トランスアミナーゼが100u以下に安定した時点でステロ イド剤を中止したところ，ステロイド剤中止による rebound 現象が起こり e 抗体に seroconversion した. 6 例中 1 例は e 抗体に seroconversion してからさらに14カ月後, HBs 抗原が RIA 法 でも陰性となりさらに 6 力月後, HBs 抗体が出現した.

索引用語：HBe 抗体 HBe 抗原 seroconversion コルチュステロイド療法 rebound 現象

はじめに

Magnius") らにより発見された HBe 抗原, HBe 抗 体 (以下 e 抗原, e 抗体) は, その後, 岡田らにより, 感染の重要な marker になることが報告された2). HBs 抗原陽性慢性肝炎に拈ける e 抗原, e 抗体の臨休的意 義については快,4,5)，e抗原陽性例にトランスアミナーゼ の変動が著しく，組織学的に む lobular change が多 いことも報告されている。これらの事を考え合せると， e 抗原から e 抗体へ seroconversion することが, 臨床 上望まれることである。しかし，e 抗原から e 抗体に seroconversion した症例の報告は少ない,8,9).今回, 我々は, HBs 抗原陽性慢性肝炎に，ステロイド剂使用 をし，免疫抑制状態をつくり，その後，ステロイド剂中

\begin{tabular}{|c|c|c|}
\hline \multicolumn{3}{|c|}{ * 虎の門病院消化器科 } \\
\hline ** & 同 & 血清検査室 \\
\hline *** & 同 & 病理学科 \\
\hline
\end{tabular}

止, 或いは滅量により, 急性肝炎と同様の状態が起こる ことを利用して，e 抗原陽性から e 抗体陽性に seroconversion した症例を 6 例経験したのでステロイド剤の 使用量，及びステロイド剤の中止時期と e 抗原から e 抗体へ seroconversionする時期との関連性について若干 の考察を加克て報告する。

\section{対象およひ方法}

対象：1972年 4 月から1980年 6 月までに虎の門病院分 院に入院し, 腹腔鏡, 肝生検を施行した HBs 抗原及 び e 抗原陽性の慢性肝疾患31例を対象とし, 特に e 抗 原陽性時にステロイド阂を使用した 6 例について検討し た.

HBs 抗原は, R-PHA 法・RIA 法, HBs 抗体は, RHA 法・RIA 法で, e 抗原 e 抗体は Micro Ouchterlany 法 によった. 検查は，原則として外来では，平均月 1 回， 入院中は，週 1 回の割で HBs 抗原・抗体; e 抗原 - e 抗体を徐索した。組織学的分類は，ヨーロッハ分類を用 
W, chronic persistent hepatitis (以下 $\mathrm{CH}$ (1)), chronic aggressive hepatitis II a (以下 $\mathrm{CH} 2 \mathrm{~A}$ ), chronic aggressive hepatitis II b (以下 CH2B), 肝硬変 (以下 LC) に 分類した。

\section{成 績}

I. e 抗原陽性訮炎31例における, e 抗体への seroconversion $の$ 頻度についで (Table 1).

i ) 31 例 の組織学的診断は, $\mathbf{C H}$ (1) 3 例 (10\%), $\mathrm{CH}$ (2A) 15例 (48\%), CH (2B) 7 例 (23\%), LC 6 例 $(19 \%)$ で $\mathrm{CH}(2 \mathrm{~A})$ の頻度が高かった。

ii ）e 抗原陽性例31例のらち, e 抗原持続陽性例は, 14例 $(45 \%)$, e 抗原 e 抗体共陰性に移行した症例は, 1 例 ( $3 \%)$, e 抗体に seroconversion した症例は16例 (52\%)であった。

iii） e 抗原陽性例 31 例中，CS 剤を使用した症例は，
6 例認められ，いずれる e 抗原陽性時に CS 剂を使用 し，その後 CS 剂を中止後に血清トランスアミナーゼ の再上昇が起り, 再び血清トランスアミナーゼが改善し た時点で e 抗体に seroconversion $L$, e 抗体が以後陽 性となった。

iv）CS 剤を使用しなかった25例です10例（40\%）に e 抗体へ seroconversion が認められたが，らち4例に reversed-seroconversion が認められた。

II. ステロイド用使用により $\mathbf{e A g}$ から $\mathbf{e A b} に$ seroconversion した症例呈示

症例 1.K.S., 38歳, 男性, 会社員 (Fig. 1)

既往歷：特記すべき事なし

翰血歴 : なし, 黄疸歴 : なし.

家族歴 : 父76歳高血圧, 母67歳脳出血にて死亡. 妻が 婚約中に急性肝资西患。

Table 1. Correlation between seroconversion from $\mathrm{HBeAg}$ to $\mathrm{HBeAb}$ and corticosteroid therapy

\begin{tabular}{|c|c|c|c|c|c|}
\hline $\begin{array}{l}\text { change of } \\
\mathrm{HBeAg} / \mathrm{Ab}\end{array}$ & $\mathrm{CH}(1)$ & $\mathrm{CH}(2 \mathrm{~A})$ & $\mathrm{CH}(2 \mathrm{~B})$ & LC & total \\
\hline$+1-\rightarrow+1-$ & $\square \square$ & $\begin{array}{llll}30 & 31 & 31 & 39 \\
\square & \square & \square & \square \\
\square & \square & 0 & \bigcirc \\
43 & 57 & 37 & 62 \\
\end{array}$ & $\square \square$ & $\square \square$ & $\begin{array}{c}14 \\
(45 \%)\end{array}$ \\
\hline$+1 \rightarrow \rightarrow-1-$ & & $\begin{array}{l} \\
73 \\
\end{array}$ & & & $\left(\begin{array}{l}1 \\
(3 \%)\end{array}\right.$ \\
\hline$+/-\rightarrow-1+$ & $\square$ & $\begin{array}{l}2734373841 \\
\square \\
\bigcirc \\
28\end{array}$ & $353643 \quad 3543$ & $\begin{array}{r}40406065 \\
\square 06\end{array}$ & $\begin{array}{c}16 \\
(52 \%)\end{array}$ \\
\hline total case & $3(10 \%)$ & $15(48 \%)$ & $7(239)$ & $6(199)$ & 31 \\
\hline
\end{tabular}

: male, steroid therapy case, $\square:$ male, non therapy case

: female, steroid therapy case, $O$ : female, non therapy case

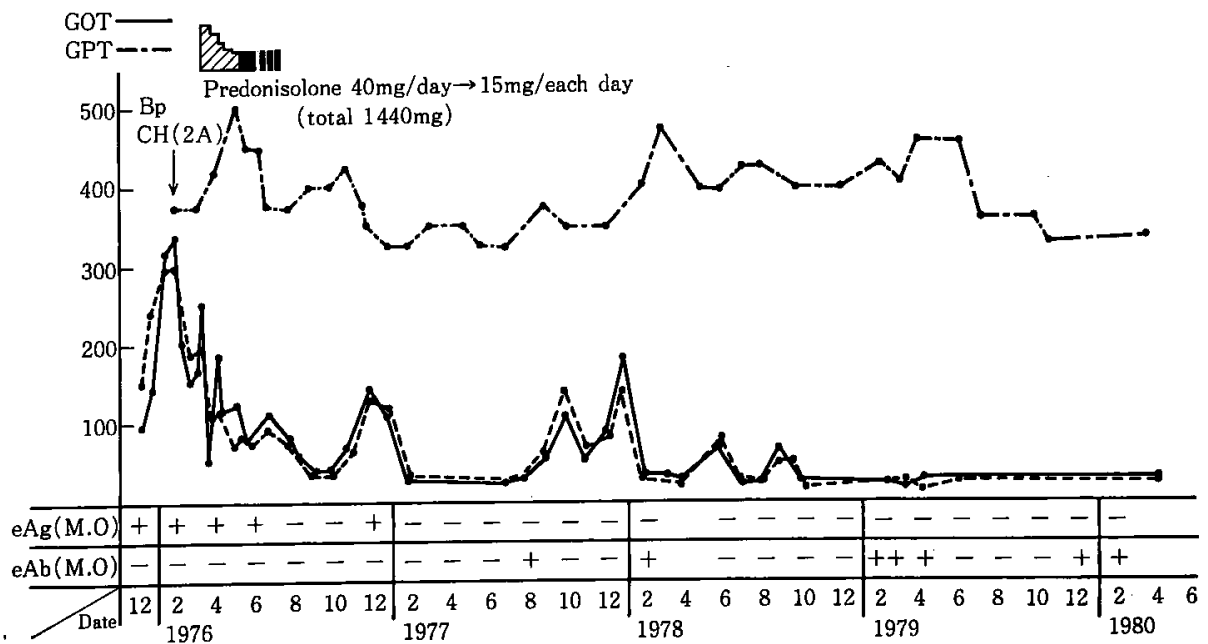

Fig. 1 Clinical course Case-1 K.S. 38y. M. 
Table 2. Case 1 laboratory findings on admission

\begin{tabular}{|c|c|c|c|c|c|}
\hline \multicolumn{2}{|c|}{ Serum protein } & \multicolumn{2}{|c|}{ Biological test } & \multicolumn{2}{|c|}{ Serological test } \\
\hline T. protein & $8.0 \mathrm{~g} / \mathrm{d} l$ & $\mathrm{Na}$ & $139 \mathrm{mE} \mathrm{q} / \mathrm{L}$ & CRP & \pm \\
\hline Alb & $62.0 \%$ & $\mathrm{~K}$ & $4.6 \mathrm{mEq} / \mathrm{L}$ & $\mathrm{RA}$ & $1+$ \\
\hline$\alpha_{1} \cdot \mathrm{gl}$ & $3.9 \%$ & $\mathrm{Cl}$ & $101 \mathrm{mEq} / \mathrm{L}$ & ASLO & $1: 80$ \\
\hline$\alpha_{2}-g l$ & $4.9 \%$ & BuN & $14 \mathrm{mg} / \mathrm{d} l$ & HBsAg & $(+)$ \\
\hline$\beta-\mathrm{gl}$ & $7.7 \%$ & Creatinine & 1.0 & & SubtypeAdr \\
\hline$r \cdot \mathbf{g l}$ & $21.5 \%$ & Uric acid & $6.3 \mathrm{mg} / \mathrm{d} l$ & HBsAb & $(+)$ \\
\hline T. Bilirubin & $1.1 \mathrm{mg} / \mathrm{d} l$ & Blood & & & SubtypeAntiw \\
\hline D. Bilirubin & $0.6 \mathrm{mg} / \mathrm{d} l$ & $\mathrm{RBC}$ & $513 \times 10^{4}$ & $\begin{array}{l}\mathrm{HBeAg} \\
\mathrm{HBeAh}\end{array}$ & $(+)$ \\
\hline TTT & 14.9 & $\mathrm{Hb}$ & $15.5 \mathrm{~g} / \mathrm{d} l$ & $\begin{array}{c}\text { HBeAb } \\
\text { Urinalysis }\end{array}$ & $(-)$ \\
\hline ZST & 11.7 & $\mathrm{Ht}$ & $44.9 \%$ & $\begin{array}{l}\text { Unnalysis } \\
\text { Protein }\end{array}$ & $(-)$ \\
\hline Ch-Ease & 0.9 & Ret & $1 \%$ & Sugar & $(-)$ \\
\hline GOT & $310 \mathrm{u}$ & WBC & 5200 & Bilirubin & $(-)$ \\
\hline GPT & $300 \mathrm{u}$ & St 11, Seg 47, & E $0, B 1$ & Urobilinogen & $(+)$ \\
\hline LDH & $331 \mathrm{u}$ & $\begin{array}{l}\text { M 2, Ly } 39 \\
\text { Thr }\end{array}$ & $18.4 \times 10^{4}$ & Faces & \\
\hline Al-P & 7.1 KA. u & $\begin{array}{l}\text { Thr } \\
\text { ICG }\left(15^{\prime}\right)\end{array}$ & $20 \%$ & Occult blood & $(-)$ \\
\hline$r-\mathrm{GTP}$ & $19 \mathrm{u}$ & $\operatorname{BSP}\left(45^{\circ}\right)$ & $22.5 \%$ & Prasite & $(-)$ \\
\hline
\end{tabular}

领酒歴 : $2 \sim 3$ 合/ 1 回, 週 $1 \sim 2$ 回 10 年間.

現病瀝：昭和 50 年10月中旬倦急感出現した為, 近医を 受診したところ，肝障害を指摘された。昭和50年12月 8 日当院受診 L, HBs 抗原陽性の慢性肝资を疑われ，昭 和51年 1 月19日当院第 1 回目の入院をした。常用薬はな w.

入院時，手掌紅斑なく，眼球結膜，黄疸，貧血なし， 心音整, 肝蔵は, 肋弓下に一横指径触知し辺縁鈍, 硬度 はやや硬く，表面は平滑であった。脾胹は, 触知しなか った。神経学的には，異常所見は認められなかった。

入院時検査成續では，血中トランスアミナーゼの上昇 (GOT 310>GPT 300), LDH 331, 膠質反心応の上昇, 血 清鉄の上昇，ICG 20\%，BSP 22.5\%と遅延が認められ た. HBs 抗原は, R-PHA 法で $2^{7}$ 以上と高值で e 抗 原も陽性であった（Table 2)。

臨床経過：入院第 4 日目の血中トランスアミナーゼ が，最高の值 (GOT 340, GPT 340) をしぬす時点での 昭和51年 1 月23日，腹腔鏡，肝生検を施行した。腹腔鏡 では，旰㯖は大きく，表面はほぼ平滑で，わずかに微細 な俩凹を認めた．色調は，白色調で毛細血管が目立つ.

脾蔵は，大きく赤白色で膨大していた。

肝生検組織像では，肝小葉構造は乱れ，グリソン鞘は すべて揳状，あるいは円形に拡大している．抎大したグ リソン鞘には膠質線維が密に増生し，小円形細胞の密な 浸潤が怹められる. piece meal necrosis も多く認めら れ，その他に小葉内に. focal necrosis が多発し，いわゆ
る CH (2A) の急性増悪の所見であった。

肝生検後, 血中トランスアミナーゼの安静化により一 旦, GOT 150, GPT 170代に改善してきたが, 昭和51年 2 月下旬より再び上昇するため 3 月 5 日よりプレドニデ ロン 40mg を使用し 5 日ごとに $10 \mathrm{mg}$ 隇少し、トランス アミナーゼは, GOT 144, GPT 177 まで改善した。し かし，3月21日より $20 \mathrm{mg}$ 隔日投与に減量した所，トラ ンスアミナーゼの再上昇（GOT 249, GPT 207) が括こ った。 その為，3月31日より $15 \mathrm{mg}$ 連日投与に变光，4 月22日退院した. その後, 外来にて $15 \mathrm{mg}$ 隔日に減量し 6 月 9 日, HBs 抗原の titer は $2^{9}$, GOT 86, GPT 86 の時点でステロイド剂を中止した。

プレドニゾロン $40 \mathrm{mg}$ を連日使用し，5 日ごとに $10 \mathrm{mg}$ ずつ溸减していた.プレドニゾロン使用後，血中トラン スアミナーゼは, ゆっくりした経過軽快していった。ス テロイド剂は, 合計プレドニデロンにて $1,440 \mathrm{mg} 85$ 日 間使用した。

ステロイド剂使用中は，HBs 抗原は， $2^{7} か ら 2^{12}$ の間 で変動し， e 抗原は，持続陽性であった。12月23日に血 中トランスアミナーゼ（GOT 164，GPT 247）の再上昇 があり陰性たった e 抗原が，再び一過性に陽性となっ た.しかし，その後は，血中トランスアミナーゼは安定 しステロイド剤中止後，13カ月目の昭和52年 7 月 20 日に e 抗体が出現した.

その後, 昭和52年 9 月と 12 月に GOT 200 までの再上 昇が認められたのを最後に, 血清トランスアミナーゼは 


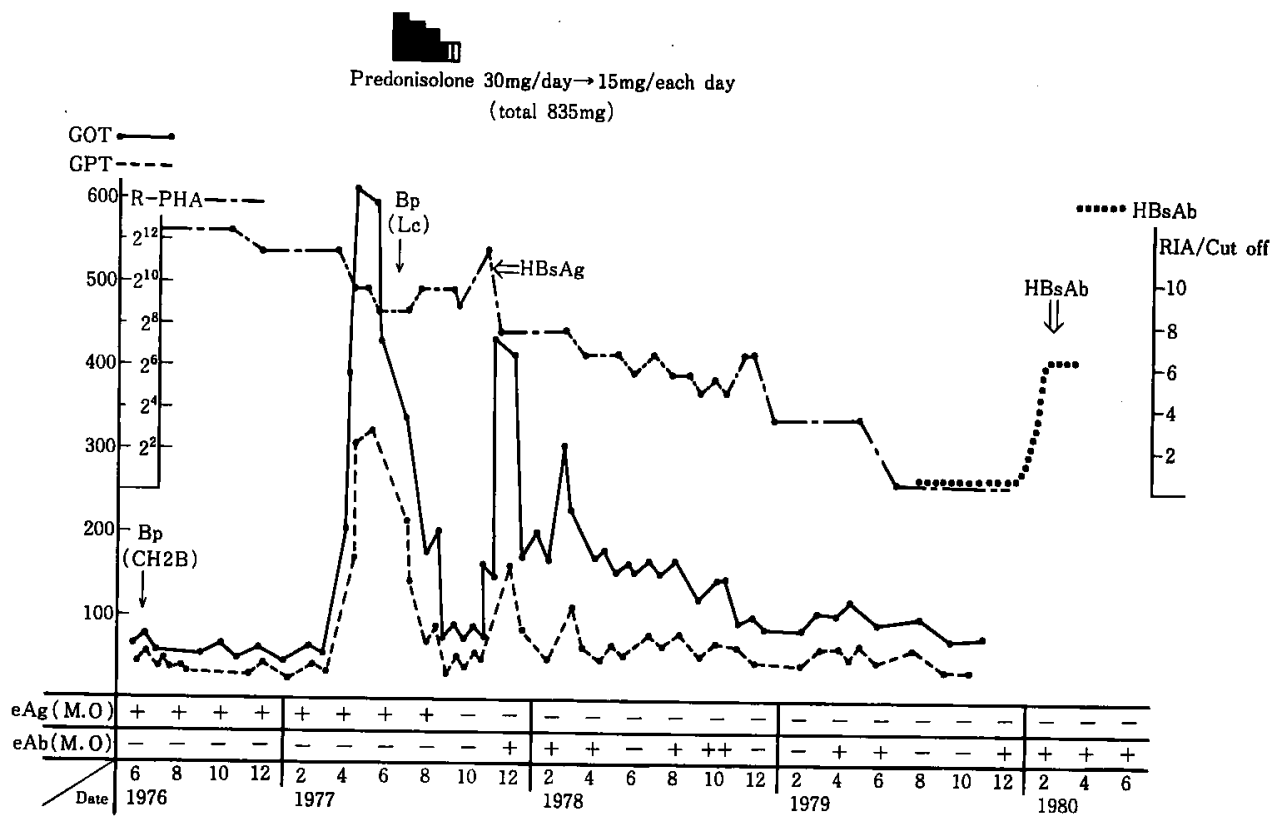

Fig. 2 Clinical course Case-2 S.Y. 67y. F.

安定化し e 抗体が陽性の現在, 経過観察中である.

症例 2 . S.Y., 67歳, 女性, 主婦 (Fig. 2)

輸血歴 : 黄疸歴 : 家族歴 : 飲酒歴 : なし.

現病歴：昭和50年 7 月近医で訮機能異常を指摘された が，自覚症状がないため放置. 昭和51年 4 月精査のため 当院第 1 回入院した。常用薬はない，入院時，肝藏は剣 状突起下三横指径触知 $\mathrm{L}$, 辺縁鈍, 硬度は弾性軟, 王痛
なし．脾臟は，触知しなかった。神経学的には，異常所 見は認められなかった。

入院時検查成績：入院時, HBs 抗原は陽珄で, 血中 トランスフミナーゼは軽度上年し（GOT 61>GPT 40）, $\boldsymbol{r}$-g1 $23.5 \%$ ，ICG $22.5 \%$ BSP $12.5 \%$ と遅延していた (Table 3).

臨床経過：入院第 15 日目の昭和 51 年 6 月 4 日に, 第 1

Table 3. Case 2 laboratory findings on admission

\begin{tabular}{|c|c|c|c|c|c|}
\hline \multicolumn{2}{|c|}{ Serum protein } & \multicolumn{2}{|c|}{ Biological test } & \multicolumn{2}{|c|}{ Serological test } \\
\hline T. protein & $8.0 \mathrm{~g} / \mathrm{d} l$ & $\mathrm{Na}$ & $140 \mathrm{mEq} / \mathrm{L}$ & CRP & + \\
\hline Alb & 59.1 .96 & $\mathrm{~K}$ & $4.2 \mathrm{mEq} / \mathrm{L}$ & $\mathrm{RA}$ & - \\
\hline$\alpha_{1}-\mathrm{gl}$ & $3.5 \%$ & $\mathrm{Cl}$ & $100 \mathrm{mEq} / \mathrm{L}$ & ASLO & $1: 80$ \\
\hline$\alpha_{2}-\mathrm{gl}$ & 4.896 & BuN & $18 \mathrm{mg} / \mathrm{d} l$ & $\mathrm{HBs} A \mathrm{~g}$ & $(+)$ \\
\hline$\beta-\mathrm{gl}$ & $9.1 \%$ & Creatinine & 0.8 & $\mathrm{HBsAb}$ & $(-)$ \\
\hline$r-\mathrm{gl}$ & $23.5 \%$ & Uric acid & $5.1 \mathrm{mg} / \mathrm{d} l$ & $\mathrm{HBeAg}$ & $(+)$ \\
\hline T. Bilirubin & $0.9 \mathrm{mg} / \mathrm{d} l$ & Blood & & $\mathrm{HBeAb}$ & $(-)$ \\
\hline D. Bilirubin & $0.5 \mathrm{mg} / \mathrm{d} l$ & RBC & $453 \times 10^{4}$ & Urinalysis & \\
\hline TTT & 22.1 & $\mathrm{Hb}$ & $13.4 \mathrm{~g} / \mathrm{d} l$ & Protein & \pm \\
\hline ZST & 13.8 & $\mathrm{Ht}$ & $41.7 \%$ & Sugar & - \\
\hline Ch-Ease & 0.9 & Ret & $2 \%$ & Bilirubin & - \\
\hline GOT & $61 \mathrm{u}$ & WBC & 3100 & Urobilinogen & + \\
\hline GPT & $41 \mathrm{u}$ & St $11, \mathrm{Se}_{\mathrm{g}}$ & , E 1, B 0 & Faces & \\
\hline $\mathrm{LDH}$ & $177 \mathrm{u}$ & M 7, Ly & & Occult blood & $(-)$ \\
\hline Al-P & $8.7 \mathrm{KA} . \mathrm{u}$ & Thr & $10.9 \times 10^{4}$ & Prasite & $(-)$ \\
\hline$r-\mathrm{GTP}$ & $13 u$ & $\begin{array}{l}\text { ICG } \\
\text { RSP }\end{array}$ & $22.5 \%$ & & \\
\hline & & BSP & $12.5 \%$ & & \\
\hline
\end{tabular}


回腹腔鏡肝生検を施行した.

組織学的には, $\mathrm{CH}$ (2B) で複小葉珄の偽小葉が一部 形成しており，その中に諗められるグリンン鞘は著しく 拡大し，小葉内に隔壁様に琹原線維が伸びていて，小円 形細胞浸潤む軽度に梕められた．入院中，血中トランス フミナーゼは，150以下に安定していたため，昭和51年 6 月28日退院した.その後，外来にて経過観察してい

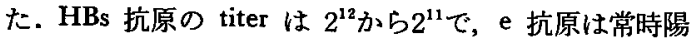
性であった。

昭和52年 3 月になり感冒に䍜患し，血中トランスフミ ナーゼが，急に上昇（GOT 589>GPT 289）したため, 昭和52年 5 月26日第 2 回目の入院をした。この時点で は, HBs 抗原の titer は, $2^{9} て ゙ \mathrm{e}$ 抗原は陽性であり, 腹腔鏡, 肝生検で, 肝硬変へ進行していた. 血清トラン スアミナーゼの上昇に対し，プレドニゾロン $30 \mathrm{mg} を$ 1 週間使用し，以後 1 週間ごと $20 \mathrm{mg}$ と漸减し $15 \mathrm{mg}$ 隔日投与した。ステロイド郕は，2力月間使用し総量は $835 \mathrm{mg}$ 使用した. 血中トランスアミナーゼは, GOT, GPT が100以下になったため, 昭和52年 9 月30日退院し た。

退院時の血中トランスアミナーゼは, GOT 73, GPT 33で HBs 抗原の titer は29 で, e 抗原, 抗体共に陰性 であった，退院後，本人が勝手にステロイド剤を中止し たため退院 1 カ月後, 昭和52年10月30日に血中トランス アミナーゼ(GOT 445, GPT 305) の再上昇があり, その後 GOT, GPT がやや低下した. 昭和52年12月10日 に e 抗体が陰性となった。しかし，昭和53年 2 月に三
たび血中トランスアミナーゼの上昇があり，その後血中 トランスアミナーゼが改善した時点で $\mathrm{e}$ 抗体が再出現 した。その本症例は昭和54年 6 月, HBs 抗原は, R-PHA 法・RIA 法であ陰性となり, 同年12月には, RIA 法で HBs 抗原が出現した.

症例 3 . H.K., 41歳, 男性, 新聞記者

既往歴：特記すべきこと無し。

輸血歴：なし.

家族歴 : 肝疾患なし.

飲酒歴：なし.

現病歴: 昭和46年 1 月末, 全身倦怠感, 吐気があり, 同年 3 月急性肝炎として某病院に入院，約 1 力月の安静 にてデータ正常化した為退院.この時, 黄疸 はなかっ た.しかし，同年 5 月より易疲労感があり，肝機能再び 悪化の為, 当院受診し 6 月 12 日入院した.

入院時, GOT 390, GPT 680,であったが，安静によ り，7月6日は GOT 21，GPT 25 まで改善し，その時 行なった肝生検では, chronic aggressive hepatitis (2A) であった。 その後, 昭和48年 5 月に GOT $770, \mathrm{GPT}$ 980 の血清トランスアミナーゼの悪化があり，昭和49年 6 月には, GOT 137, GPT 280, 同年 9 月 GOT 166, GPT 223，炤和50年 4 月には, GOT 300, GPT 448 の 血清トランスアミナーゼの悪化があった．HBs 抗原は， 昭和 46 年 2 月から昭和 48 年 3 月まで ES 法にて, 断続的 に陽性であった。昭和48年 3 月より昭和50年 6 月まで は，HI 法 IA 法で持続陽性となった.

昭和50年 6 月より R-PHA では, HBs 抗原の titer は,

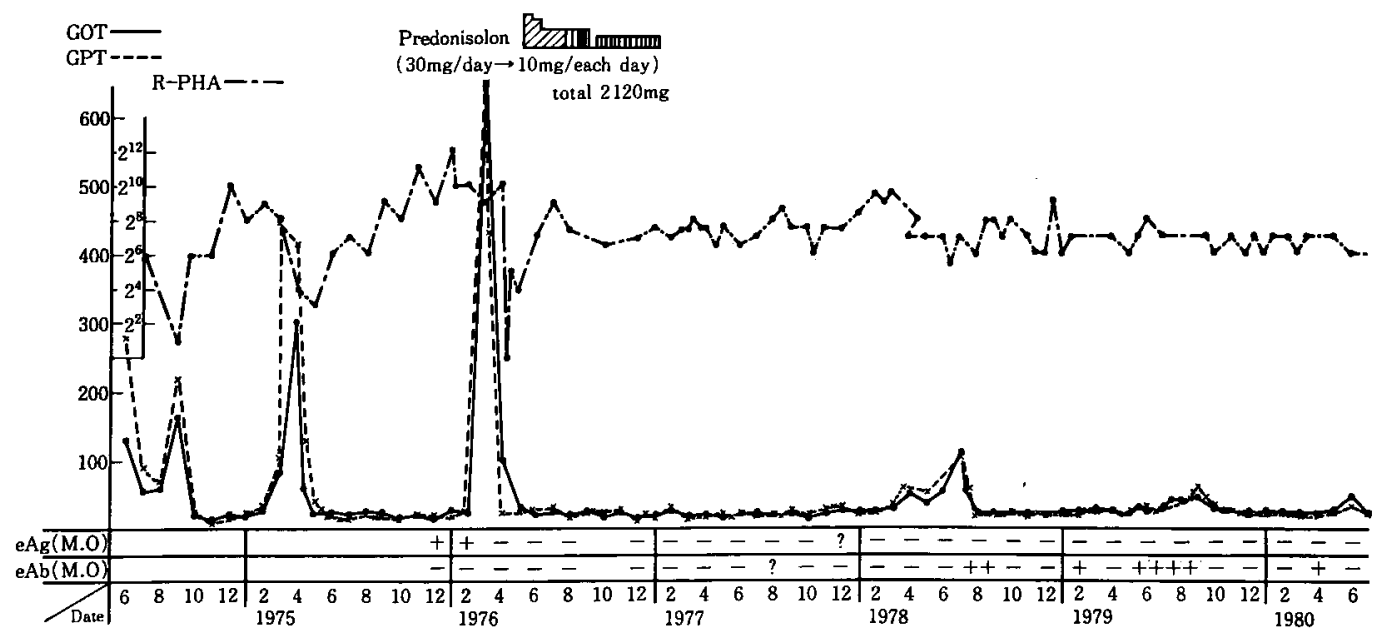

Fig. 3 Clinical course Case-3 H.K. 41y. M. 
$2^{1} \sim 2^{12}$ までを変動し，血清トランスアミナーゼの上昇時 には, HBs 抗原の titer は低下し, 血清トランスアミ ナーゼの低值の時は，HBs 抗原の titer は高值を呈して いた。昭和51年 1 月 7 日の検査で，昭和50年12月より测 定し始めた $\mathrm{e}$ 抗原が陽性となり，同時に测定した DNA ポリメラーゼも陽性となった。この時点では，HBs 抗 原の titer は, $2^{10}$ で GOT 24, GPT 21 であったが, 2 カ月後には, GOT 1400, GPT 1400 となった為, 第 2 回目の入院となり，4月16日，腹腔鏡，肝生検を施行 L, chronic aggressive hepatitis (2B) と進行しており, 5 月 6 日よりプレドニゾロン $30 \mathrm{mg}$ を 10 日間連日， 25 $\mathrm{mg}$ を14日間連日，15mg 30 日間連日，15mg を隔日 にて30日，以後，10mg を隔日にて 8 カ間 total 2,120 $\mathrm{mg}$ を使用した所，血清トランスアミナーゼは，正常化 し，昭和53年 1 月12日には e 抗体が出現した。以後， 昭和53年 6 月に GOT 108，GPT 170 の血清トランスフ ミナーゼの上昇を最後に，昭和55年 8 月までの 2 年以 上，血清トランスアミナーゼは正常化し，e 抗体が断続 的に陽性となった.

症例 4 . H.W., 36歳, 男性, 教師 (Fig. 4)

既往歴：17歳の時, 肺結核にて三考療法 6 力月受け た。

家族歷 : 肝疾患なし.

輸血歷：なし.

飲酒歴：2 合/日 $\times 10$ 年間
昭和53年12月 6 日健康診断にて, 尿糖之肝機能異常を 指摘された。12月13日には GOT 350 の為, 某病院に入 院した。昭和54年 2 月14日 GOT 138, GPT 177 の為, プレドニゾロン $30 \mathrm{mg}$ を使用し 1 週間ごとに $5 \mathrm{mg}$ ずつ 減量し続け 3 月28日より $10 \mathrm{mg}$ 使用の時点で GOT 70 , GPT 100 となり，3月31日よりプレドニゾロン $5 \mathrm{mg}$ 合 計 $585 \mathrm{mg}$ で退院となった。 4 月 5 日，当院に外来受診 乙, GOT 96, GPT 191 で HBs 抗原の titer は $2^{8}$ で e 抗 原陽性であった．この時点でステロイド斉を中止した。 4 月11日の入院時では, GOT 230, GPT 281, HBs 抗原 の titer は2 $2^{\mathrm{s}}$, e 抗原は陽性であった。入院後, rebound とおむわれる GOT, GPT の上昇があり，4月20日， GOT, GPT の極期に近い腹腔鏡，肝生検を施行した所， chronic aggressive hepatitis (2B) で piece meal necrosis も強く, lobular change \& confluent necrosis 伴う激 しいものであった４月23日には，GOT 860，GPT 705 の上昇があり e 抗原 $\mathrm{e}$ 抗体は陰性化した. その後 GOT, GPT は改善し 6 月 1 日には GOT 27, GPT 25まで改善 した. HBs 抗原の titer は, $2^{7} \sim 2^{8}$ の間でほとんど変動 はなかった。

昭和54年 6 月 2 日，GOT 27, GPT 25, HBsAg の titer $2^{7}$ で退院した. 退院後 GOT は50以下, GPTは100 以下で安定し，経過順調であった．HBs 抗原の titer は， $2^{7} か ら 2^{2}$ と変動は少なかったが，8月13日 eAb 陽性 となった。

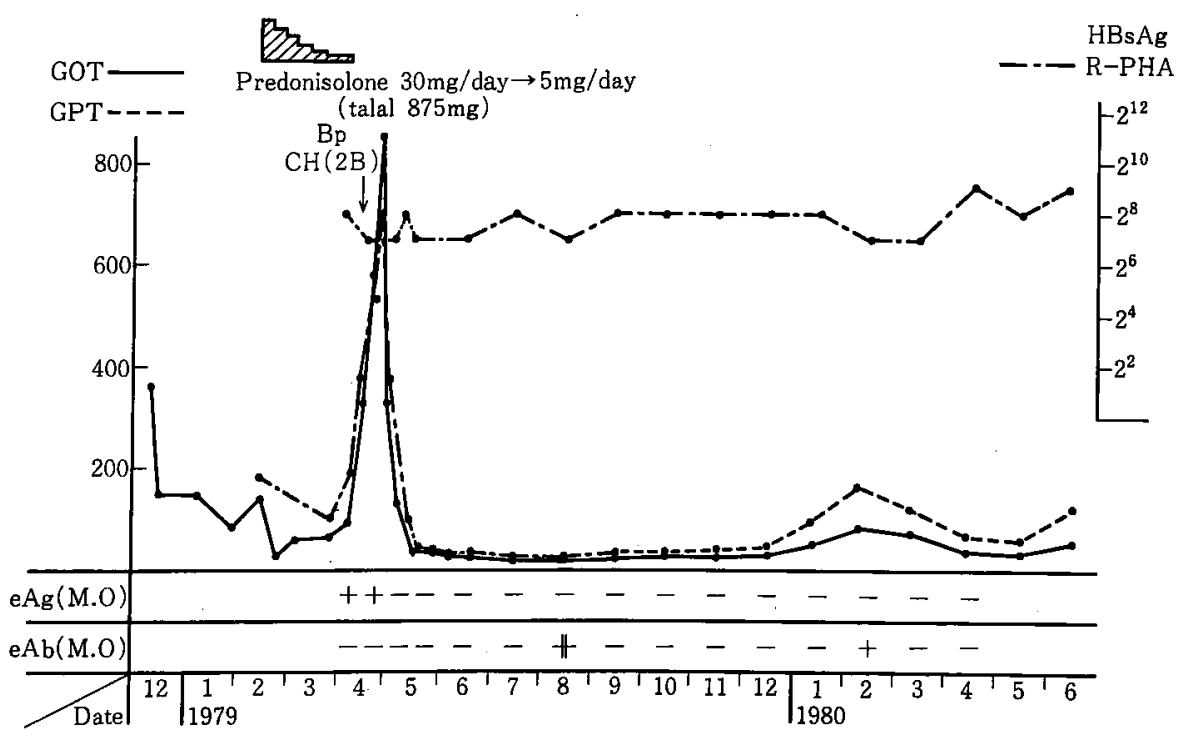

Fig. 4 Clinical course Case-4 H.W. 


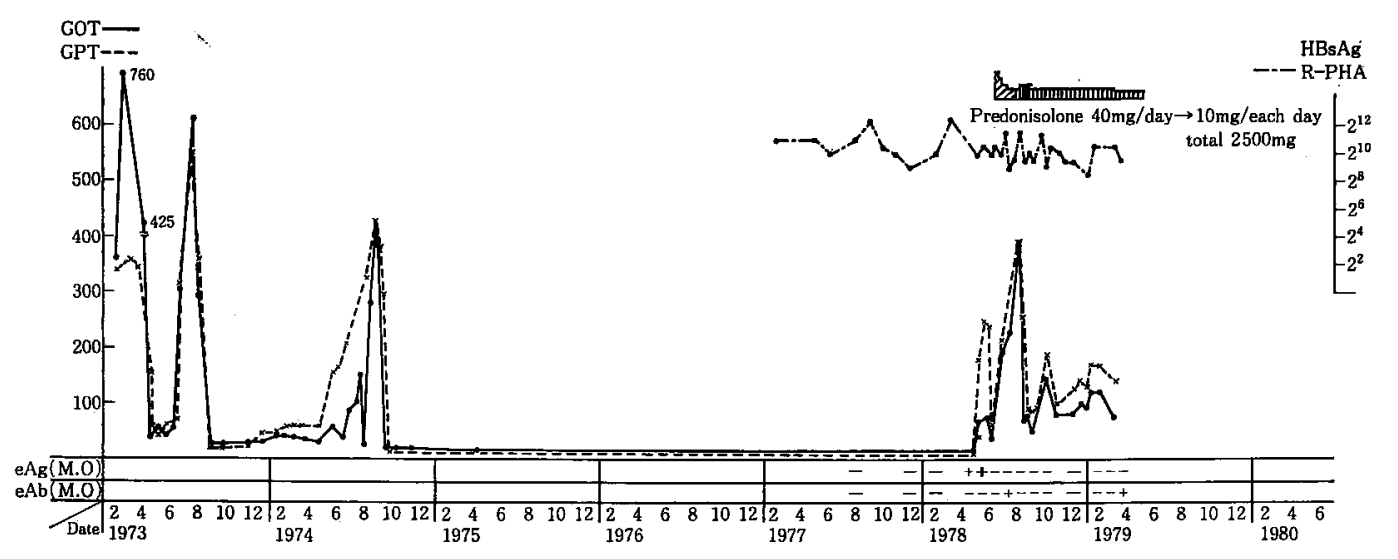

Fig. 5 Clinical course Case-5 A.M. M.

症例 5. M.A., 50歳, 男性, 公務員 (Fig. 5)

既往歴：特記すべきことなし。

輸血歴：なし.

家族歴 : 母方の祖父, 祖母共《腹水貯留, 母 : 69藏, 肝硬変, 母の姉妹 2 人肝硬変, 姉; HBs 抗原陽性.

飲酒歴：ビール 1 本/日 $\times 30$ 年間

現病歴：昭和 48 年 2 月，呕気があり黄疸出現，当院 受診し急性肝炎といわれ，3月6日入院した．入院時 GOT 590，GPT 500 であったが，入院後，安静のみで GOT, GPT は急速に改善し，3 月24日には GOT 144, GPT 216の時点で腹腔鏡, 肝生検を行った所, CH (2B) と診断された。 HBs 抗原は IA 法で2 $2^{11}$ と陽性であっ た. その後, GOT, GPT は改善し50前後となり 6 月 5 日に退院した。退院後, 外来で 1 回/月経過観察してい た. 昭和 49 年 6 月から 8 月まで 3 力月間 GOT 380 の上 昇があったが，外来でそのまま経過観察していた所，昭 和 49 年 9 月には正常化した。 その後，昭和53年 4 月まで GOT は，ほぼ正常化していた．昭和53年 4 月20日， GOT 49, GPT 62 であり HBs 抗原の titer は2 $2^{11}$ 之高值 であった．昭和52年 8 月より測定していた e 抗原・e 抗体は，いずれも陰性であった。昭和53年 5 月11日， GOT 121, GPT 180, HBs 抗原の titer は, $2^{12}$ で e 抗 原が陽性となった為，5月15日第 2 回目の入院，入院 時, GOT 101, GPT 183 と徐々に上昇し 6 月 2 日, GOT 124, GPT 232. この e 抗原陽性の時点で, 腹腔鏡, 肝 生検を施行した所, 肝硬変のはじまりの像であった。 又, 小葉内の肝細胞の崩壤もつよい為，6月 6 日よりプ レドニゾロン $40 \mathrm{mg}$ を連日 5 日間投与， $30 \mathrm{mg}$ を連日 5 日間，6月17日より $30 \mathrm{mg}$ を隔日投与に漸減した所，6
月20日には GOT 25，GPT 40 まで著しい改善をみた。 HBs 抗原の titer は，ステロイド剤投与後も $2^{10}$ と変動 はなかった。 $\mathrm{eAg}, \mathrm{eAb}$ は陰性となった。 6 月23日より プレドニゾロン $20 \mathrm{mg}$ 隔日，7月11日より $15 \mathrm{mg}$ 隔日， 減量した頃より GOT, GPT の再上昇があり，8月 2 日 には GOT 389, GPT 387 の再上昇が認められた。この 時点で eAb が陽性となった． 8 月 8 日よりプレドニゾ ロン $20 \mathrm{mg}$ 隔日に堌量し経過をみていた所, GOTは, ゆっくりした経過で改善し，10月14日，GOT 145, GPT $188, \mathrm{HBs}$ 抗原 titer $2^{10}, \mathrm{eAg}, \mathrm{eAb}$ 共陰性化した時, 一旦退院，外来で経過観察とした．外来で 2 週間に 1 回 の割で経過をみていた所，GOT 80〜130，GPT 130〜 160の間を小幅ながら変動していた.HBs 抗原 titer は, $2^{8} \sim 2^{10}$ を変動していた。 $\mathrm{eAg}, \mathrm{eAB}$ が昭和 54 年 3 月 22 日 に陽性となった以外は，いずれる陰性であった．その 後，本人が昭和54年 4 月より転勤となったが，現在（55 年 7 月), GOT, GPT は正常化している.

症例 6.S.M., 36歳, 男性, 会社員 (Fig. 6)

既往厢 : 昭和40年, 胃潰瘍以外になし.

輸血歷：なし。

家族歴：父系祖父75歳肝癌.

現病歴：昭和53年 5 月まで肝機能は調べたことはなか った。昭和53年 5 月20日，上腹部不快感・吐気・呕吐が ある為, 近医受診した所, HBsAg 陽性肝障害指摘され た. 昭和53年 6 月 6 日に入院，プレドニゾロン $20 \mathrm{mg}$ 1 週間使用した。 しかし，中止後 GOT, GPT が再上 昇する為，昭和54年 6 月18日，当院受診した。受診時 GOT 74, GPT 115, HBs 抗原の titer は, $2^{9} て ゙ \mathrm{e}$ 抗原 陽性であった．外来にて 2 週間に 1 度経過観察していた 


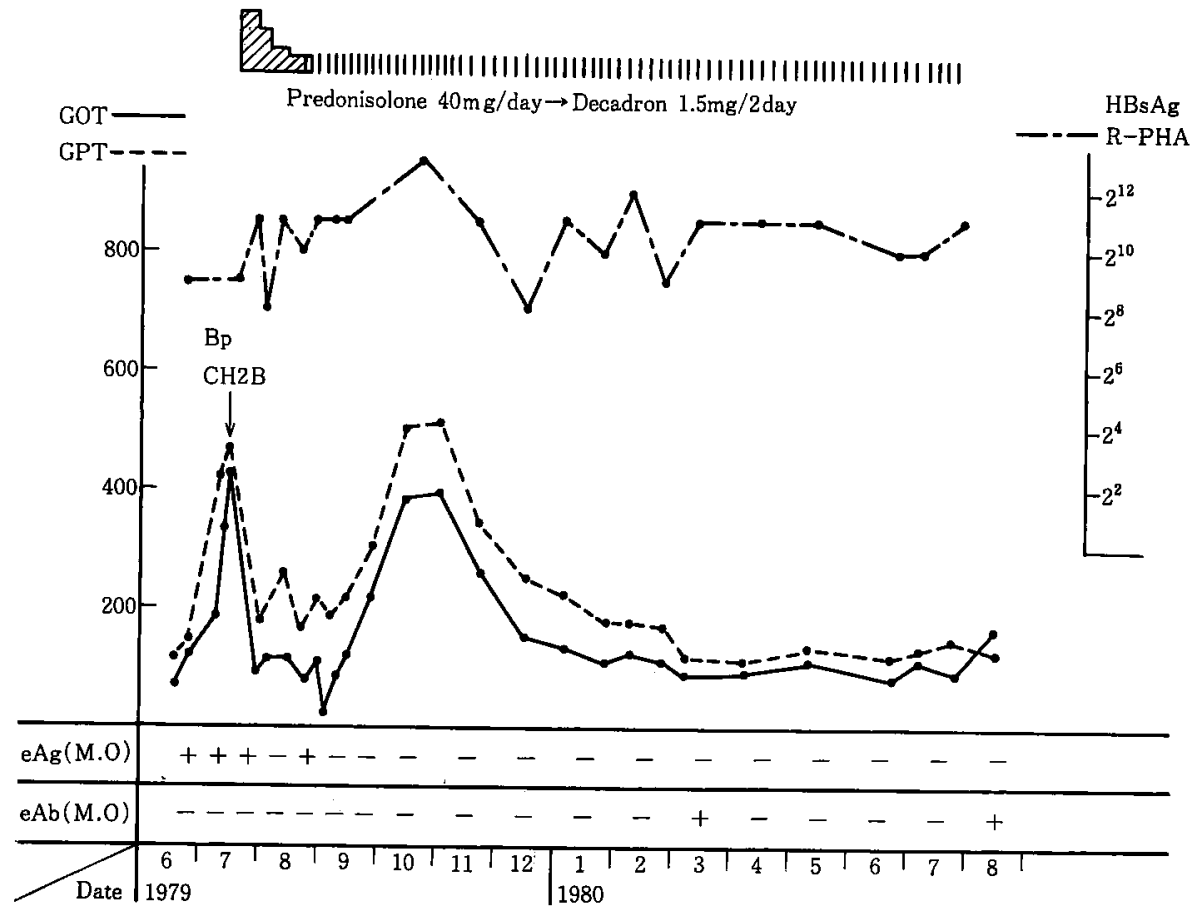

Fig. 6 Clinical course Case-6 S.M. 37y. M.

が, GOT, GPT が上昇するため 7 月10日，当院入院. 入院時 GOT 340, GPT 412, HBs 抗原 titer $2^{11}$ で e 抗原陽性であった。 7 月20日, 腹腔鏡, 肝生検を施行し た所, $\mathrm{CH}$ (2B) で, 腹腔鏡的に赤点があり, 又肝生検 にて lobular change が強い為，7月23日よりプレド= ゾロン $40 \mathrm{mg} 7$ 日間，30mg 7 日間使用し 8 月 9 日には GOT 116, GPT 218, HBs 抗原の titer $2^{11}$ と不変, e 抗原陽性であった． 8 月 7 日よりプレドニゾロン $20 \mathrm{mg}$
に漸減したが，GOT，GPT は平行状態の為，8月14日 よりデカドロン $1.5 \mathrm{mg}$ を10日間使用し，8月19日より $1.5 \mathrm{mg}$ を隔日投与に減量して 9 月10日，デカドロン 1.5mg. GOT 124, GPT 207, HBs 抗原 titer $2^{13}$. e 抗 原・e 抗体陰性の時点で退院した。退院後の9月27日よ りステロイド剤減量による rebound と思われる GOT 228, GPT 300, 11月 1 日には GOT 395, GPT 505 の rebound があり, 以後 GOT, GPT は徐々に改善し, 昭

Table 4. Seroconversion cases from $\mathrm{HBeAg}$ to $\mathrm{HBeAb}$ by steroid therapy

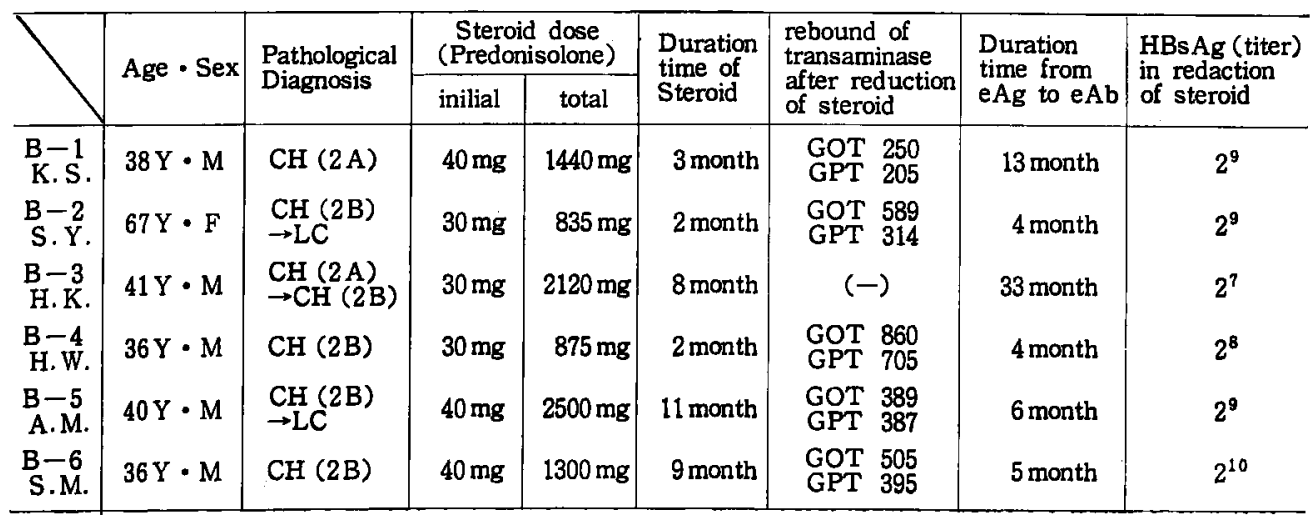


和55年 3 月 6 日, GOT 93, GPT 123, HBs 抗原 titer $2^{11}$ の時点で e 抗体が出現した. 7 月14日，GOT 127 , GPT 132, HBs 抗原 titer $2^{10}$ の時点でデカドロン $1.0 \mathrm{mg}$ を中止した，現在，経過観察中である.

III. ステロイド剤使用例のまとめ (Table 4)

ステロイド剂を使用し, e 抗原から e 抗体へ seroconversion した6例をまとめたのが Table 3である. 年齢 は36歳から67藏までで20歳台には使用しなかった。組織 学的には, ステロイド使用前の 肝生検組織䛦断は, $\mathrm{CH}$ (2A) 2 例，CH (2B) 4 例であったが，経過を追って 肝生検を施行できた 3 例では，いずれる一段階，すな わち $\mathrm{CH}(2 \mathrm{~A})$ の症例は, $\mathrm{CH}(2 \mathrm{~B}) k, \mathrm{CH}(2 \mathrm{~B})$ の 症例は LC に進行していた. e 抗原から e 抗体への seroconversion の期間は, 最短 4 カ月で最長 33 力月であ ったが，33カ月であった症例 3 は，ステロイド中止後に も rebound がなかった唯一の例であった. ブレドニゾ ロン使用量は, 初回量 $30 \mathrm{mg}$ 及び $40 \mathrm{mg}$ として $5 \sim 7$ 日間ごとに $10 \mathrm{mg}$ ずつ減量し $10 \mathrm{mg}$ 或いは $20 \mathrm{mg}$ の時 点で隔日投与にし， 3 カ月以上の長期使用を原則とし た.ステロイド剤中止或いは，減量中の血清トランスフ ミナーゼの rebound は， 6 例中 5 例に認められた. 又， rebound を起こした 5 例のいずれもが， rebound 時の最 高值が GOT が GPT に比して高かったことが注目され た.

\section{考案}

HBs 抗原持続陽性肝炎火招ける e 抗原から e 抗体へ の seroconversion 症例の報告は少ない.鈴木ら 抗原から e 抗体へ seroconversion 寸る症例では, HBe 抗体への変換に伴なって病変の非活動性の傾向が見ら れたと報告している。，又，我々は，すでに e 抗原か ら e 抗体に seroconversion した症例を報告した. 又, seroconversion の際は, 血中トランスフミナーゼの上昇 が，高頻度に認められることも報告してきた．今回，31 例の e 抗原陽性の慢性肝疾患を経過観察中 6 例にステ ロイド剤中止後, 或いは減量中に e 抗体が出現してい た.このことから，今日，ステロイド用と e 抗原から e 抗体への seroconversion との関係について検討した. 臨床的には，一般にステロイド剤を使用すると血中トラ ンスアミナーゼは減少するが，漸減，中止すると血中卜 ランスフミナーゼの再上昇を招くことは，良く知られて いる.我々の経験ではこの症例を更に経過観察している と，ステロイド㶡中止後しばらくして，血中トランスフ ミナーゼか，徐々に安定してくる. 今回, 我々が経験し
たステロイド剤使用例 6 例は，ステロイド剂中止後， 3 カ月から 2 年の間に $\mathrm{e}$ 抗体が出現していた.

すな方ら, e 抗体出現時期と血中トランスアミナーゼ の安定時期が一致しておりステロイド剤中止後に生体反 応が強く起こり, 急性肝炎と同様の起序で $\mathrm{e}$ 抗原から e 抗体に移行することで，肝炎の活動が弱まったと考え られる.

また,ステロイド剤中止後の GOT, GPT の再上昇の 程度の大きい程，e 抗体陽性になる時期が早いといら傾 向も認められた。この事実は, ステロイド剂中止後, 免 疫反応の強さに比例すると考点れば十分説明しらる。

従来，ステロイド剤の使用は，慢性肝炎の場合，肝生 検にて Bridging necrosisを伴なった慢性肝炎, 或は, 西小葉肝壊死を伴なった慢性肝炎に使用すべきと考え られていたが，今回，我々が経験した症例のごとく $\mathrm{CH}$ (2B) Kステロイド剂を使用して, e 抗体陽性になって, 肝機能が安定化しても肝硬変に移行してしまっては，い ずれ肝癌の発生も考立杖ばならない。しかし，CH (2A) でステロイド剂を使用すれば，たとえ $\mathrm{CH}$ (2B) Kなっ ても e 抗体になった時点が早ければ慢性肝炎の進行は ゆっくりとなり天寿を全らしえるか, 或いは肝硬変に なっても高龄まで生きることが可能となると思われる。 また，ステロイド剂中止後, 免疫賦活剤使用により, 早 く e 抗原から e 抗体に移行を助長することもできると 思われる．しかし，現時点ではステロイド剂の使用にあ たっては，慎重を期すべきであり，ステロイド剂の中止 に上る強い免疫反応が起り, 劇症化する恐れがあること も十分に考虑しなければならない，劇症化の関連につい て, 今回我々の症例では，ステロイド剤中止の時期を HBs 抗原の血中 titer が, $2^{7} \sim 2^{10}$ と比較的低、時期に行 なった。

今回，ステロイド剤を使用した所 HBs 抗原の titer は高くなったが，長期使用し，漸减すると HBs 抗原の titer は下がってきた。この上うに，HBs 抗原の titer が低くなるのをまって，ステロイド剤を中止すれば，劇 症化の恐れは少ないまた 6 例中症例 2 では, e 抗原か ら e 抗体に seroconversion したのみならず HBs 抗原が 消失し, HBs 抗体が出現した。本症例は，ステロイド 剂を急に中止し GOT · GPT の rebound も著しく大き かった事が HBs 抗原にまで seroconversion した要因で 急性肝炎と同し状態か人工的に作り出された為と思われ る.従がってこのステロイド郕中止後の rebound を利用 し，HBs 抗原の持続感染を断つことができれば，HBs 
抗原陽性の慢性肝炎の大きな治療法となると思われる。 結語

過去 8 年間に, 虎の門病院分院にて 旰生検をしえた $\mathrm{HBe}$ 抗原持続陽性肝疾患31例のらちステロイド剤を使 用して e 抗原から e 抗体に seroconversion した 6 例に ついて検討した。

1) e 抗原から e 抗体に seroconversion した症例 6 例いずれるステロイド剂, 減量あるい忡止後, 4 カ月 から 2 年以内に e 抗体が出現していた。

2）ステロイド剤の中止は，HBs 抗原の血中 titer $2^{7} \sim 2^{10}$ の間でいずれる劇症化はなかった。

3）ステロイド剂を使用し，eAg から eAbに seroconversion した 6 例中 1 例に, HBs 抗原が消失 L HBs 抗体が出現した。

以上の結果より，ステロイド剤は中止後血中トランス アミナーゼの再上昇を伴ない，生体反応が强く再現さ れ，e 抗原から e 抗体に seroconversion させると考え られた，今後慢性肝炎に対して，ステロイド斉の使用時 期も含めて検討すべきと思われる.

本論文の要旨は，第15回日本肝臓学会総会で報告した。 本論文作成に御指導いただいた自治医大真弓忠教授， 又御手伝い下さった虎の門病院中込仁子嫎に深謝しま 于.

\section{文献}

1) Magnius, L.O. \& Espmark, J.A.: New specificities in Australia antigen positive sera distinct from Le Bouvier determinants. J.
Immunol., 109: 1017, 1972.

2) Okada, K. et al.: e antigen and anti-e in the serum of symptomatic carrier mothers as indicators of positive and negative transmission of hepatitis B virus to their infants. New Engl. J. Med., 294: 746, 1976.

3）赤羽賢浩他：HBs 抗原陽性肝疾患および無症 侯性 HBs 抗原 carrier に和ける $\mathrm{HBe}$ 抗原. 肝藏, $21: 391,1980$.

4) Smith, J.L. et al.: Studies of $e$ antigen in acute and chronic hepatitis. Gastroenterology, 71: 208, 1976.

5) Eleftheriou, N. et al.: Incidence and clinical significance of e antigen and antibody in acute and chronic liver disease. Lancet, II: 1171, 1975.

6) Sheikh, N.E. et al.: e antigen-antibody system as indicator of liver damage in patients with hepatitis B antigen. Brit. Med. J., 4: 252, 1975.

7) 能田博光他：e抗原, e 抗体陽性例の肝組織像. 肝葴, $18: 692,1977$.

8）熊田博光他：e 抗原, e抗体の seroconversion K 関する検討. 肝缄, $20: 734,1979$.

9) Realdi, G. et al.: Seroconversion from hepatitis $B$ e antigen to anti-e in chronic hepatitis B virus infection. Gastroenterology, 79: $195,1980$. 


\section{Study of the seroconversion from e-Ag to $\mathrm{e}-\mathrm{Ab}$ by corticosteroid treatment in the HBs positive chronic hepatitis

\author{
Hiromitsu Kumada, Akira Yoshiba, Eiji Oyake, Kenji Ikeda*, \\ Kikue Fujisawa, Ikuko Wakabayashi, Sachiko Seto, \\ Toshiyasu Tsurada** and Yuzo Endo***
}

In 6 chronic hepatitis patients who had been seropositive for both $\mathrm{HBeAg}$ and $\mathrm{HBs} A g$, the seroconversion from $\mathrm{HBeAg}$ positive to anti-HBe positive was induced by the rebound phenomenon of serum transaminase caused at the end of corticosteroid medication or during its gradual reduction. All of the 6 patients had been given 30 to $40 \mathrm{mg}$ of steroid medicine daily while they had been seropositive for HBeAg and maintained a high level of serum transaminase. Subsequently the dose had been gradually reduced over periods ranging from 2 months to 1 year. When the serum HBeAg titer had dropped to $2^{8}$ to $2^{10}$ and the serum transaminase had been stabilized at less than $100 \mathrm{u}$., steroid medicine administration was stopped and seroconversion was observed following the rebound phenomenon caused by this discontinuation.

In one of the patients HBsAg became negative even in the radioimmunoassay at 14 months after the seroconversion into anti-HBe positive, and at 6 months following this anti-HBs also appeared in the serum.

\footnotetext{
* Department of Digestive Organs, Toranomon Hospital (Tokyo)

** Department of Serology.

*** Department of Pathology.
} 